\title{
Quality Evaluation of Milk at Different Levels of Milk Chain System in Makwanpur District, Nepal
}

\author{
BEDANANDA BHATTARAI ${ }^{*}$ and SIYARAM PRASAD SINGHA ${ }^{2}$
}

\author{
${ }^{1}$ Himalayan College of Agricultural Sciences and Technology (HICAST), Gattaghar, \\ Bhaktapur, Nepal \\ ${ }^{2}$ Dairy Development Corporation (DDC), Lainchaur, Kathmandu, Nepal
}

\begin{abstract}
This study assessed the quality of raw milk produced by District Milk Producers Co-operative Union (DMPCU) Makawanpur, Nepal. Five different stages (i.e. farmers, co-operative, chilling center, raw milk storage tank and pasteurization) were taken. The study revealed that adulteration was not common problem, however water addition was found to be $2.6 \%$ at farmer's level with increase up to the $18.7 \%$ at pasteurization. Decrease in the level of conductivity from 4.32 to $3.25 \mathrm{mS} / \mathrm{cm}$, ash from 0.76 to $0.64 \%$, fat from 5.38 to $2.96 \%$, SNF from 9.06 to $7.93 \%$, Lactose 4.44 to $3.81 \%$ and protein from 3.1 to $2.5 \%$ was noticed from farmer's to pasteurization level. Increase in Coliform from $4.9 \log 10 \mathrm{CFU} / \mathrm{ml}$ to $5.5 \log 10 \mathrm{CFU} / \mathrm{ml}$ from farmer's level at raw milk to storage tank was noticed with simultaneous decreased in MBRT from 237 to 99 min. Pasteurization reduced Coliform up to zero with increased in MBRT up to $309 \mathrm{~min}$.
\end{abstract}

Keywords: District milk producer cooperative union, Milk chain, Quality, Coliform, Methelene blue reduction test

\section{Introduction}

Although the dairy business has a great opportunity in Nepal, to maintain the quality for whole milk chain seems to be a great challenge for the sustainability of the dairy business. Nepalese dairy business is still in primitive stage. To modernize and commercialize this business, a systematic approach yet to be implemented from farm to fork. Assessment of the quality at different levels of milk chain is the prime aim for implementing good quality assurance approach to produce wholesome, hygienic and commercially potential milk and milk products (Dairy Cooperative, 2010).

More than $80 \%$ of milk is collected through milk cooperatives in organized sector. There are more than 38 district milk producers' co-operative unions (DMPCU) in country (Dairy Cooperative, 2010). Most of them have been involved in milk business. This study was aimed to evaluate the quality aspect of milk at the different level of milk chain (i.e. Farmer to CoOperative, Co-Operative to Chilling Center, Chilling Center to Processing Plant, Processing Plant to Marketing) in Makawanpur district, Nepal.

\section{Materials and Methods}

The methodology adopted to conduct this study was divided into three parts. At first phase, preparatory works for sampling design and sample management were carried out. Secondly, sample collection and laboratory testing were carried out and thirdly data processing was done. Sampling points were comprised of individual farmers, milk collection at dairy cooperatives, chilling centers, dairy processing plant and just after pasteurization of the milk in dairy.

\footnotetext{
* Corresponding author, E-mail: bnbhattarai646@hotmail.com
}

The test kit for detection of adulterants in milk developed by National Dairy development Board Anand-388001, Gujarat was used for the Qualitative analysis of urea, starch and cereal flours, sugar/sucrose, salt and neutralizer. Lactoscan machine (LACTOSCAN SA, MILKANALYZER, LCD display - 4 lines x 16 characters, HEAD OFFICE, 4, Narodni Buditeli Str., 8900 Nova Zagora, BULGARIA) was used for the analysis of water content, fat, SNF, protein, lactose, conductivity, freezing point and ash as per the Milkotronic Operation Manual (2008). The machine was standardized with the equipment of HMSS, which was already standardized by them with standard equipment of DFTQC. Coliform count and MBRT were done according to DDC (2001).

\section{Statistical analyses}

Statistical Packages for the Social Science (SPSS) (version 13) was used for statistical analysis and Microsoft Office Excel 2007 program was used for graphical presentation of data. One way ANOVA with no blocking design was used for the analysis of test statistics at $95 \%$ level of confidence. A mean comparison test was performed using Tukey HSD program.

\section{Results and Discussion}

Adulteration: The different types of adulteration were assessed in milk chain of DMPCU and the result is given in Table 1.

From the result, the adulteration test for urea, starch, sugar, salt and neutralizer in all milk samples (i.e.126 samples) of each stage from farmer level to milk packet was found to be negative. This might be due to the awareness programmes organized by DMPCU/DDC. Training conducted by DMPCU/ DDC might be effectively implemented up to the farmers' level. 
This result is in line with the DDC test record kept in DDC laboratory (DDC, 2010). It shows that adulteration (except water addition) was not the common problem in Makwanpur district milk chain during this study. In case of water addition, the value was found to be continuously increased $(\mathrm{p}<0.05)$ from $2.6 \%$ at farmers' level to $18.72 \%$ at after pasteurization level (Table 1). The reason may be due to the addition of water in different stages. This indicates the trend of adding water from farmers' level to raw milk storage is common practice in DMPCU.

Physico-chemical quality: Physico-chemical quality of milk was assessed and the result for fat, SNF, protein, lactose, conductivity, freezing point and ash contents are given in Table 2 .

According to the result, the value for fat was found to be continuously decreased $(\mathrm{p}<0.05)$ from $5.38 \%$ at farmer's level to $2.96 \%$ at after pasteurization level. The value for SNF was found to be continuously decreased $(p<0.05)$ from $9.06 \%$ at farmer's level to $7.93 \%$ at after pasteurization level. The value for protein was found to be continuously decreased $(p<0.05)$ from $3.1 \%$ at farmer's level to $2.52 \%$ at after pasteurization level. The value for lactose was found to be continuously decreased $(p<0.05)$ from $4.44 \%$ at farmer's level to $3.81 \%$ at after pasteurization level. The value for ash was found to be continuously decreased $(\mathrm{p}<0.05)$ from $0.76 \%$ at farmer's level to $0.64 \%$ at after pasteurization level. (Table 2). The reason may be due to the addition of water
The value for conductivity was found to decrease from 4.32 at farmer's level to 3.25 after pasteurization. The value was found to be significantly $(\mathrm{p}<0.05)$ reduced from farmers level to cooperative/chilling center level and was again found to be reduced from milk storage tank to after pasteurization (Table 2). The reason may be due to the dilution of milk, centrifugation step during processing. The conductivity value of cow milk, sheep milk and buffalo milk should be between 4 to 6,3 to 5 and 2.5 to $5 \mathrm{mS} / \mathrm{cm}$ at $18^{\circ} \mathrm{C}$ (Milkotronic Operation Manual, 2008). The conductivity value depends on the geographical reason and breed. Added water, sugar, proteins, insoluble solids are responsible for decrease in ion's concentrations. Added salt increases the value of conductivity. Value more than 6.5 to 13.0 indicates the development of mastitis. Infections damage the tissue of udder and allow sodium and chlorides ions from the blood to be released into the milk. The concentration of ions in the milk is thereby raised and can more easily conduct an electrical current, due to this reason the conductivity increases. Similarly milk conductivity can be used as tests for degree of water evaporation and condense milk production (Milkotronic Operation Manual, 2008).On analyzing the significance of conductivity values, this present study shows that there may not be the problem of mastitis's and reduction of conductivity values at the later stages may be due to the increase in water content in milk.

Table 1. Adulteration test of milk sample at different level

\begin{tabular}{lcccccc}
\hline & & & & & Water \\
Stage $\backslash$ Parameter* & Urea & Starch & Sugar & Salt & Neutralizer & Addition\%** \\
\hline Farmers & -ve & -ve & -ve & -ve & -ve & $2.60^{\mathrm{a}} \pm 4.73$ \\
Cooperatives & -ve & -ve & -ve & -ve & -ve & $4.53^{\mathrm{b}} \pm 2.08$ \\
Chilling Centre & -ve & -ve & -ve & -ve & -ve & $8.74^{\mathrm{c}} \pm 2.18$ \\
Raw Milk Tank & -ve & -ve & -ve & -ve & -ve & $17.45^{\mathrm{d}} \pm 1.11$ \\
After Pasteurization & -ve & -ve & -ve & -ve & -ve & $18.72^{\mathrm{d}} \pm 1.92$ \\
\hline
\end{tabular}

*Total samples were 42 from each level, data represents triplicate value for each sample. Therefore the result is the mean value of $42 \times 3=126$ replicates \pm standard deviation in each stage. ${ }^{* *}$ Different superscripts the same column indicates the mean values are significantly different $(\mathrm{p}<0.05)$ to each other.

Table 2. Physico-chemical test of milk sample at different level*

\begin{tabular}{lccccccc}
\hline & $\begin{array}{c}\text { Fat } \\
\text { Stage } \backslash \text { Parameters** }\end{array}$ & $\begin{array}{c}\text { SNF } \\
\mathbf{( \% )}\end{array}$ & $\begin{array}{c}\text { Protein } \\
\mathbf{( \% )}\end{array}$ & $\begin{array}{c}\text { Lactose } \\
\mathbf{( \% )}\end{array}$ & $\begin{array}{c}\text { Conductivity } \\
(\mathbf{m S} / \mathbf{c m})\end{array}$ & $\begin{array}{c}\text { Freezing } \\
\text { Point }(\mathbf{- o C})\end{array}$ & $\begin{array}{c}\text { Ash } \\
(\mathbf{\%})\end{array}$ \\
\hline Farmers & $5.38^{\mathrm{a}} \pm 1.12$ & $9.06^{\mathrm{a}} \pm 0.61$ & $3.10^{\mathrm{a}} \pm 0.34$ & $4.44^{\mathrm{a}} \pm 0.36$ & $4.32^{\mathrm{a}} \pm 0.87$ & $0.531^{\mathrm{a}} \pm 0.043$ & $0.76^{\mathrm{a}} \pm 0.06$ \\
Cooperatives & $4.84^{\mathrm{b}} \pm 0.86$ & $8.69^{\mathrm{b}} \pm 0.24$ & $2.86^{\mathrm{b}} \pm 0.09$ & $4.09^{\mathrm{b}} \pm 0.13$ & $3.63^{\mathrm{b}} \pm 0.38$ & $0.497^{\mathrm{b}} \pm 0.018$ & $0.73^{\mathrm{b}} \pm 0.02$ \\
Chilling Centre & $4.31^{\mathrm{c}} \pm 0.51$ & $7.97^{\mathrm{c}} \pm 0.24$ & $2.81^{\mathrm{b}} \pm 0.11$ & $4.00^{\mathrm{b}} \pm 0.10$ & $3.61^{\mathrm{b}} \pm 0.12$ & $0.477^{\mathrm{b}} \pm 0.015$ & $0.69^{\mathrm{c}} \pm 0.01$ \\
Raw Milk Storage & $3.80^{\mathrm{d}} \pm 0.50$ & $7.88^{\mathrm{c}} \pm 0.32$ & $2.59^{\mathrm{c}} \pm 0.11$ & $3.95^{\mathrm{b}} \pm 0.18$ & $3.95^{\mathrm{c}} \pm 0.27$ & $0.522^{\mathrm{a}} \pm 0.086$ & $0.68^{\mathrm{c}} \pm 0.01$ \\
After Pasteurization & $2.96^{\mathrm{e}} \pm 0.04$ & $7.93^{\mathrm{c}} \pm 0.04$ & $2.52^{\mathrm{c}} \pm 0.05$ & $3.81^{\mathrm{c}} \pm 0.03$ & $3.25^{\mathrm{d}} \pm 0.02$ & $0.502^{\mathrm{a}} \pm 0.068$ & $0.64^{\mathrm{d}} \pm 0.02$ \\
\hline
\end{tabular}

*Sample Number was 42 from each level, data represents triplicate value of each sample, so the result is the mean value of $42 \times 3=126$ replicates \pm standard deviation in each stage.

**Different superscript letters $(\mathrm{a}, \mathrm{b}, \mathrm{c}, \mathrm{d}, \mathrm{e})$ in the same column indicates the mean values are significantly $(\mathrm{p}<0.05)$ different to each other. 
Similarly, the value for freezing point was found to slightly increased $(p<0.05)$ from -0.531 at farmers level to -0.477 chilling center (Table 2). The value was again found to be slightly decreased $(p<0.05)$ from -0.477 at chilling center to -0.507 at after pasteurization level. Milk freezes at temperature slightly lower than water due to the presence of soluble constituents such as lactose and soluble salts, which lower or depresses the freezing point. The average freezing point depression of Indian cow milk may be taken as $-0.547^{\circ} \mathrm{C}$ and buffalo milk $0.549^{\circ} \mathrm{C}$. Most bulk milk samples have a freezing point depression of $-0.530^{\circ} \mathrm{C}$, a freezing point depression lower than this value indicates added water. Mastitis milk shows a normal freezing point. The freezing point test of milk is highly sensitive one and even upto $3 \%$ of watering can be detected (De, 1993). While the freezing point of normal milk is remarkably constant and employed mainly for the detection of adulterants of milk with water, souring results in a lowering of the freezing point due to increase in the amount of soluble molecules. Hence freezing point should be determined on the samples which have not been soured for greatest accuracy. Boiling and sterilization increases the value of freezing point depression, but pasteurization has no effect. The fat and protein content of milk have no direct effect on the freezing point of the milk (De, 1993). The results of the present study also support these facts and the changes of freezing point may be due to addition of water.

Microbiological quality: Microbiological quality in milk chain of DMPCU was assessed and the result for coliform and MBRT test is given in Table 3.

Table 3. Microbiological quality of milk in milk chain of DMPCU*

\begin{tabular}{|c|c|c|}
\hline Stage $\backslash$ Parameter** & $\begin{array}{c}\text { Coliform } \\
(\mathrm{Log} 10 \mathrm{CFU} / \mathrm{ml})\end{array}$ & $\begin{array}{c}\text { MBRT } \\
\text { (Minute) }\end{array}$ \\
\hline Farmers & $4.9^{\mathrm{a}} \pm 0.25$ & $237^{\mathrm{a}} \pm 36$ \\
\hline Cooperatives & $5.3^{\mathrm{b}} \pm 0.44$ & $167^{b} \pm 24$ \\
\hline \multicolumn{3}{|l|}{ Chilling Centre } \\
\hline Level & $5.3^{\mathrm{b}} \pm 0.33$ & $125^{\mathrm{c}} \pm 28$ \\
\hline Raw Milk Storage & $5.5^{\mathrm{c}} \pm 0.25$ & $99^{\mathrm{d}} \pm 15$ \\
\hline After Pasteurization & $0^{\mathrm{d}}$ & $309^{e^{e}} \pm 18$ \\
\hline \multicolumn{3}{|c|}{$\begin{array}{l}\text { * Sample Number was } 36 \text { from each level, data represents triplicate } \\
\text { value of each sample, so the result is the mean value of } 36 \times 3= \\
108 \text { replicates } \pm \text { standard deviation in each stage. }\end{array}$} \\
\hline \multicolumn{3}{|c|}{$\begin{array}{l}\text { ** Different superscript letters }(\mathrm{a}, \mathrm{b}, \mathrm{c}, \mathrm{d}, \mathrm{e}) \text { in the same column } \\
\text { indicates the mean values are significantly } \mathrm{p}<0.05) \text { different to } \\
\text { each other. }\end{array}$} \\
\hline
\end{tabular}

According to the result, the value for coliform count in milk was found to be significantly increased $(\mathrm{p}<0.05)$ from $4.9 \mathrm{log}$ $10 \mathrm{CFU} / \mathrm{ml}$ at farmer's level to $5.5 \log 10 \mathrm{CFU} / \mathrm{ml}$ at raw milk storage tank (Table 3 ). However the value was significantly reduced to zero level after pasteurization. Similarly, the value for MBRT in milk was found to be continuously decreased $(\mathrm{p}<0.05)$ from 237 at farmer's level to $99 \mathrm{~min}$ at raw mil storage tank (Table 3). However the value was again significantly increased from 99 at raw milk storage tank to 309 min after pasteurization.

The methylene blue reduction test (MBRT) is based on the fact that the color imparted to milk by the addition of a dye such as methylene blue will disappear more or less quickly. The removal of the oxygen from milk and the formation of reducing substances during bacterial metabolism cause the color to disappear. The agencies responsible for the oxygen consumption are the bacteria. Though certain species of bacteria have considerably more influence than others, it is generally assumed that the greater the number of bacteria in milk, the quicker will the oxygen be consumed, and in turn the sooner will the color disappear. Thus, the time of reduction is taken as a measure of the number of organisms in milk although actually it is likely that it is more truly a measure of the total metabolic reactions proceeding at the cell surface of the bacteria (Atherton and Newlander, 1977). The result supports the fact that MBRT is correlated to the value of coliform, the higher the microbial load, the lower will be the MBRT value and vice versa.

\section{Conclusion}

Milk Samples collected from milk chain of DMPCU of Makwanpur district were found to be unadulterated (in terms of urea, starch, salt, sugar and neutralizer) at all the stages from farmer to processing level. However water addition was found to be increased from around $2 \%$ to around $18 \%$ from farmer level to industry level. Regarding Physico-chemical quality; Fat, SNF, Protein and Lactose were found to be significantly reduced from farmer's level to the consumer packet. Ash was found to be slightly reduced (from 0.76 to $0.64 \%$ ) from farmer's level to processing plant. Regarding microbiological quality of milk, coliform bacteria was found to be increased from 4.89 to $5.54 \log 10 \mathrm{CFU} / \mathrm{ml}$ from farmers to raw milk storage tanks; however the level of coliform was reduced to zero after pasteurization. MBRT value was found to be decreased from 237 to 99 minute from farmers to raw milk storage tank, which was found around 309 after pasteurization. Trend between coliform and MBRT was found to be associated to each other. Further investigation on adulteration, Physico-chemical and microbiological quality is encouraged including different DMPCU's available in Nepal.

\section{Acknowledgements}

The authors are thankful to Mr. Chooda Mani Bhandari (Program Manager, FAO Nepal office) for providing Lactoscan and technical support; to Dr. Satrughan Prasad Shah (Factory Manager, HMSS) for providing laboratory facilities and to all the team members of DMPCU, Makawanpur for providing samples and logistic support during the course of this study. 


\section{References}

Atherton H. V. and Newlander J. A. (1977). Chemistry and Testing of Dairy Products, $4^{\text {th }}$ edn. AVI, Westport, CT.

CBS (2008). Figures in Nepal, Central bureau of Statistics, Government of Nepal.

Dairy Cooperative (2010). Dairy Cooperative Central Office, New Baneshwor, Kathmandu.

DDC (2001). Dairy development corporation Laboratory Manual.
De S. (1993) Outlines of Dairy Technology, Oxford university press, Delhi, Bombay, Calcutta, Madras, Printed at Raj Bandhu Industrial Co., New Delhi 110064 and published by Neil O’Brien, Oxford University Press YMCA Library Building, Jai Singh Road, New Delhi 110001, pp 14, 16.

Milkotronic Operation Manual (2008). LACTOSCAN SA, MILK ANALYZER, LCD display - 4 lines x 16 characters, HEAD OFFICE, 4, Narodni Buditeli Str., 8900 Nova Zagora, BULGARIA, www.lactoscan.com, www.milkotronic.com, pp 90, 91.

NDDB Manual (2001). Laboratory Handbook for Dairy Industry, Kathmandu, Nepal 